Berlin and Heidelberg, and specialized in the biological sciences. His many researches fall into groups, to each of which he made contributions of value : the histology of the sense-organs, nervous system and musculature of various molluscs; the anatomy and histology of the aberrant Temnocephala linking Turbellaria and Trematoda ; studies on spermatozoa and experiments on ciliary movement and Protozoa, including his work on the geotaxis of Paramecium. In Edinburgh he concentrated upon physiological problems relating to sex.

But the most striking of all Merton's achievements was his expedition to the south-east Moluccas, undertaken on behalf of the Senckenbergischen Naturforschenden Gesellschaft. From October 1907 until August 1908 he explored the Aru and Kei Islands, bringing home vast zoological collections, the description of which by experts occupies two large volumes published at Frankfurt-am-Main in 1911 and 1913. The catholicity of his own interests is shown by his 200-page introductory account of the geography and ethnology of the islands.

Dr. Merton is survived by his widow, to whom the late Prof. Max Weber paid the compliment of dedicating one of his new species of fish from the Moluccas, on the ground that throughout she took an active part in the labours of her husband.

JAmes Ritchie.

\section{Prof. Pierre Marie}

Prof. Pierre Marie, the celebrated French neurologist, whose death took place recently, was born on September 9, 1853, in Paris, where he received his medical education and qualified in 1883 with a thesis on the incomplete forms of Graves' disease, which afterwards became a classic. After serving as Charcot's chief assistant at La Salpêtrière he was elected physician in 1885 to the Bicêtre Infirmary, where he set up a rich collection of interesting records of cases, specimens and photographs of various diseases of the nervous system and attracted a large number of practitioners and students, many of whom have become distinguished neurologists. In 1907 he was elected professor of morbid anatomy in the Paris faculty of medicine in succession to Victor Cornil.

Prof. Marie made numerous valuable contributions to neurology. In addition to adding to our knowledge of well-recognized diseases such as rabies, disseminated sclerosis and epilepsy, he was the first to describe acromegaly (1886). In 1892 he brought out a book on diseases of the spinal cord which, like his articles on acromegaly, was published in English by the New Sydenham Society. In 1906 he caused a considerable sensation in the medical world by the publication of three articles on aphasia in the Semaine Médicale, in which he declared that the third left frontal convolution of the brain played no special part in the function of language, as had been maintained by Broca. During the War of 1914-18 he did valuable work in conjunction with his interne, Mme. Athanasio Benisty, on the symptoms and treatment of injuries of the nerves, which were published by her in the French "Horizon" series and in English form in the "Medical Military Manuals". In 1926 and 1928 he did good service to neurologists and others by publishing in two volumes, entitled "Travaux et Mémoires", the most important of his articles which had appeared in various periodicals and society reports. J. D. Rolleston.

\section{Prof. W. Blackadder}

Prow. W. Blackadder, who died on May 14, graduated B.Sc. in engineering in the University of Edinburgh in 1897 and was awarded the Vans Dunlop Scholarship. After graduating he gained a wide experience in general engineering practice with the Caledonian Railway, Aberdeen Harbour Commissioners and the Clyde Navigation Trust. In 1907 he was appointed lecturer in civil engineering and applied mechanics in the Royal Technical College, Glasgow, under the late Prof. Longbottom, who at one time acted as assistant to the late Karl Pearson.

Prof. Blackadder was specially interested in structural theory and hydraulics and succeeded in developing this interest in students and staff alike. His teaching bore the hallmark of the master and was always abreast of modern developments. In 1924 he was appointed as first occupant of the Jackson chair of engineering in the University of Aberdeen and succeeded in building up a most efficient department. He was deeply interested in the welfare of his students and aimed at giving a sound theoretical training in engineering science in which the teaching of practical engineering formed little part except to illustrate to some small extent the application of that science in practice.

As a result of researches into the losses in turbine pumps and flow of water in looped pipes he was awarded the D.Sc. by his Alma Mater in 1923, while in 1932 he was awarded the Telford Premium by the Institution of Civil Engineers for his paper on "Direct Methods for Construction of Influence Lines for Continuous Girders".

WE regret to announce the following deaths :

Sir James Baillie, O.B.E., formerly vice-chancellor of the University of Leeds, on June 9, aged sixtyseven.

Sir Thomas Hudson Beare, regius professor of engineering in the University of Edinburgh, on June 10, aged eighty.

Mr. Oliver Gatty, research chemist, aged thirty-two, and Mr. A. S. Chessum, research engineer, aged twenty-seven, during an experiment in connexion with air raid precautions, on June 5 .

Prof. A. E. H. Love, F.R.S., Sedleian professor of natural philosophy in the University of Oxford, on June 5.

Sir Jocelyn Thorpe, C.B.E., F.R.S., emeritus professor of organic chemistry in the University of London and in the Imperial College of Science and Technology, on June 10, aged sixty-seven. 